\title{
Signed peer review
}

Public Domain

\section{Source}

Open Research Glossary

When the individual reviews are publicly signed by those who conducted them. 